\section{Building bridges between lives}

\author{
Shirley Lindenbaum
}

Return to the High Valley: Coming Full Circle. By Kenneth E. Read. University of California Press:1986. Pp.269. \$18.95, $£ 15.95$.

KENNETH Read, the first anthropologist to work for an extended period in the New Guinea Highlands, has already provided one distinguished account of the quality of life among the Gahuku-Gama of the Asaro Valley. The High Valley (1965) took as its central themes the relations between men and women and the structuring of relationships between and within generations, although there was little evidence of an interest in anthropological theory as such. Instead, Read's search for the individuality of others and for shared moral concerns led to complex portraits of village leaders, male age mates, and the harsh and poignant ceremonies of initiation and marriage. The book was also a subjective record of self-discovery.

Return to the High Valley joins personal and professional past to present. Based on two short visits in 1981 and 1982, 30 years after the original research, it is a postcolonial work in a variety of ways. Read demonstrates his unique capacity to convey the momentous changes that have recently taken place in New Guinea, aware that those born after 1950 experienced the events in a different way from those men and women who grew up in more traditional times. The original themes thus surface again, played out now against the backdrop of the past. The transformation is captured in detail, vast and small: in the spread of a cash economy and new forms of employment, in the demise of the old ritual and ceremonial exchanges of wealth, in the growth of Goroka from a small government settlement to a town of over 10,000 people with a teachers' college and discotheque, and in the rumble of passing traffic now augmenting the small waking sounds of a rural community.

The book's post-colonial stance is also in the method of its telling. Aware of the unanticipated publicity showered on the subjects of the first volume and the ability of a younger generation to read past and present texts. the contours of the contemporary tribal political landscape are merely sketched, and detailed portraiture is reserved for persons who are dead, or for the members of Read's Gahuku family - the relatives of Makis. Makis, the most influential man of the tribe, and Read's companion, elder brother, friend and mentor from 1950 to 1952 , died in a road accident in 1969 . The "subject" of Chap- ter 2 in each book, Makis is a more constant presence in the second work, due in part to changing conventions in ethnographic writing. Although The High Valley was in many ways a precursor of current trends which attempt to find new ways to represent the voice of informants adequately, Return replaces the subjective focus of the earlier autobiography with the view that Makis is the lens through which Read acquired some comprehension of the subtleties of Gahuku life. The life observed and written about is said to be in large part a distillation of Makis, leavened, of course, by the author's own perspectives and professional training. This more complex appraisal gives authorship not to the monologue of the observing anthropologist, but to the many unwitting local contributors to the text, and conveys more accurately the way anthropological knowledge is generated in intense, interpersonal engagement.

Critical at times of some Gahuku cultural practices and of the behaviour of certain individuals, and disaffected by the

embrace of what appear to be the most vulgar elements of our own society's offerings, Return to the High Valley is, nonetheless, a work of elegant cultural translation. It is the product of a mature craftsman who confesses a love for words, for the rhythm of sentences juxtaposed within a paragraph and a delight in visual properties. The special quality of the relationship between Makis and Read is part of the magic of the book. Although diffident about the ability of outsiders to penetrate the inner worlds of others, and aware of the impediments posed by attempting to convey such understandings in the language available to us, Read's account is a testament to the creation of kinship across the boundaries of different ways of life.

Shirley Lindenbaum is Associate Professor of Anthropology, Graduate Faculty, New School for Social Research, 69 Fifth Avenue, New York, NY 10003, USA. She is also Editor of the American Ethnologist, and has made two field trips to the Eastern Highlands of Papua New Guinea.

\section{Potential of plants}

\section{W.A. Hughes}

Plant Cell Culture Technology. Edited by M.M. Yeoman. Blackwell Scientific: 1986. Pp.375. \$52.79, £34.50.

THE evolution of techniques for planttissue culture into a viable technology has been slower than might have been expected. This is due, in part, to the inherent plasticity of plant cells that defies most attempts to lay down general rules of behaviour at either the cellular or tissue level. In Plant Cell Culture Technology, M.M. Yeoman has brought together a number of leading exponents to review selected aspects of this topic. The declared aim is to provide a readable, up-to-date account (at least to early 1985) of the commercial impact and potential of plant cell and tissue culture. Emphasis throughout the book is very much of the cellular rather than molecular aspects.

The book starts particularly well, with the first 100 pages devoted to vegetative propagation. These chapters look at the role of determination (Meins), a review of general methodology (Hussey) and finish with the implications for plant breeding with particular reference to somaclonal variation (Scowcroft and Ryan). The main body of the book is taken up with several chapters dealing with those techniques that have not yet been fully exploited. The uses of cryopreservation and gene banks (Withers) is described in much detail, as is the importance of cell selection (Dix) and the perpetual attempts to make developing secondary products a profitable pro- cess (Fowler followed by Lindsey and Yeoman). Although there is much of interest here, these lengthy chapters (especially those by Withers and Dix) put the book out of balance. Indeed the contribution on genetic manipulation and cell transformation (Draper, Davey and Freeman) is relegated to the last 30 pages, and even then the focus is primarily on specific delivery systems for DNA into plant protoplasts. In an area where tissue culture may arguably yet play its most important role, I felt their view was unnecessarily limited.

Each of the authors provides a brief introduction to their area for non-specialist readers; for the researcher there is an excellent bibliography with titles. The tone throughout the book is mostly realistic the veneer of commercial application is a thin one and few, if any, attempts are made to hide this fact. The mandatory introduction and outlook are written by the editor and clearly reflect the cautious optimism of the intervening chapters. He reminds the reader that it was eight years ago that the late H.E. Street looked to the future in an earlier Botanical Monograph (Plant Tissue and Cell Culture, 1977). The problems outlined then are still with us. However, the selective choice of topics in this book has not caught the present excitement in this area. Nevertheless, there are enough ideas here to act as a catalyst for the next eight years and as such could be read profitably by serious students, young and old alike.

W.A. Hughes is a research scientist working on the biochemical aspects of plant cell differentiation at Unilever Colworth Laboratory, Sharnbrook. Bedford MK44 ILO, UK. 